\title{
Survey of edaphic fauna in forest fragment in the municipality of Anchieta (SC, Brazil)
}

\author{
Denise Brancher' \& Margarida Flores Roza-Gomes ${ }^{1,2}$ \\ ${ }^{1}$ Laboratory of Zoology and Botany, University of Western Santa Catarina - UNOESC, \\ Campus Sao Miguel do Oeste/SC Oiapoc Street, 211, Agostini Neighbourhood, \\ CEP 89900-000, São Miguel do Oeste, SC, Brazil \\ ${ }^{2}$ Corresponding author: Margarida Flores Roza-Gomes, email: margarida.gomes@unoesc.edu.br
}

BRANCHER, D. \& ROZA-GOMES, M.F. Survey of edaphic fauna in forest fragment in the municipality of Anchieta (SC, Brazil). Biota Neotrop. 12(3): http://www.biotaneotropica.org.br/v12n3/en/ abstract?article+bn02212032012

Abstract: Among the edaphic Hexapods, the insects are more abundant and important in that they act as environmental indicators. This study aimed to conduct a survey of the edaphic fauna in a forest fragment of transition from ombrophilous forest to mixed seasonal deciduous forest in the municipality of Anchieta, SC, Brazil. Samples were collected every fortnight from May to August 2010 by using the method of pitfall traps. Were collected 6598 individuals. The groups more abundant was Hymenoptera with 3398 individuals (51\%), Collembola with a total of 1370 individuals (21\%) and Diptera represented by 910 individuals (14\%). The Simpson Index was found 0.60 and the Shannon Diversity Index was 3.00. The results obtained show that the place studied by provide conditions of survival to susceptible species such as Collembola, indicated a good quality of the soil study. Keywords: insects, pitfall traps, seasonal fluctuation, soil fauna.

BRANCHER, D. \& ROZA-GOMES, M.F. Levantamento da fauna edáfica em fragmento florestal no Município de Anchieta (SC, Brasil). Biota Neotrop. 12(3): http://www.biotaneotropica.org.br/v12n3/pt/ abstract?article+bn02212032012

Resumo: Dentre os Hexapoda edáficos, os insetos são os mais abundantes e de grande importância por atuarem como indicadores ambientais. Esse estudo teve como objetivo realizar um levantamento da fauna edáfica em um fragmento florestal de transição de floresta ombrófila mista para floresta estacional decidual, no Município de Anchieta, SC, Brasil. As coletas foram realizadas quinzenalmente no período de maio a agosto de 2010 utilizando o método das armadilhas de queda tipo pitfall traps. Foram coletados 6598 indivíduos. Os grupos mais abundantes foram Hymenoptera com 3398 indivíduos (51\%), Collembola com um total de 1370 indivíduos (21\%) e Diptera representada por 910 indivíduos (14\%). O valor do Índice de Simpson encontrado foi de 0,60 e o Índice de Diversidade de Shannon de 3,00. Os resultados obtidos mostram que o local estudado por apresentar condições de sobrevivência para espécies sensíveis como os Collembola, indicam uma boa qualidade do solo da área estudada. Palavras-chave: insetos, armadilhas de queda, levantamento populacional, fauna de solo. 


\section{Introduction}

The phylum Arthropoda corresponds of the most successful to the evolution Earth (Brusca \& Brusca 2002) with approximately 1.000 .000 species (Costa Ribeiro \& Rocha 2002, Storer 2003), representing $85 \%$ of all animal species described (Brusca \& Brusca 2007).

Represents at phylum the most important ecological, because most of the energy flow of ecosystems passing through the bodies of these animals (Mota et al. 2009) and dominate all terrestrial and aquatic ecosystems in number of species or individuals or both (Storer 2003). The litter arthropod fauna stands out in forest ecosystems because of their importance in nutrient cycling and degradation of organic matter, as long as these organisms are primarily responsible for fragmenting the accumulated litter from the surrounding greenery (Ferreira \& Marques 1998).

According to Storer (2003), the class Insecta comprises over 900.000 species, are the only invertebrates that can live in dry environments and only able to fly. Represent about $70 \%$ of animal species known, therefore, represent the most numerous group existent today (Almeida 1998).

The edaphic insects are living in the soil or at least seek their resources in the ground. Are extremely important for preserving biological, chemical and physical ecosystems (Dindal 1990) and are the most sensitive to environmental impacts (Dambroz et al. 2007) and can be used as environmental indicators, revealing the conditions of the area where they are.

The edaphic invertebrates are important processes in the terrestrial ecosystems, breaking down organic matter, cycling nutrients and indirectly regulate the biological processes of soil at different levels and establishing relations with the microorganisms, which are essential for fertility and ecosystem productivity (Nunes et al. 2009).

Tropical forests provide diverse composition of litter and nutrient cycling by establishing a more stable community of diversified decomposers, This fact occurs because these forests are situated in a region where the climate is defined by one wet and one dry season (Sanches et al. 2009). The litter is composed of organic matter of animal and vegetable on the soil, at the different stages of decomposition. Thus representing a form of entry and subsequent increased soil organic matter (Barbosa \& Faria 2006).

Studies on insects may provide a rich base of information about the level of integrity of environments in which they are, as well as being the more numerous group of animals of the planet a great diversity in terms of species and habitats (Thomazini \& Thomazini 2000). Some groups of insects are especially useful in environmental monitoring, it happens because they are so diversified, easily sampled and identified, common throughout the year and responding quickly to environmental alterations (Cullen Junior et al. 2006). The main characteristic is a good indicator of sensitivity to significant changes between 01 and 03 years and 05 years as a margin limit (Lopes 2008).

To study the ecosystem is a way of knowing how the situation of the site. For this reason, many studies have been and are being performed in order to to evaluate the environmental quality, in particular the soil, which houses a large variety of animals that need it to survive is for food or shelter.

Given this, it is of fundamental importance in this survey of edaphic fauna forests. In the forest fragment studied, this type of survey was never done, so do not have information for diversity edaphic fauna and soil quality, and these data are very importance to the local community and also at regional level. In this sense, the objective of this study was to survey the edaphic fauna in the forest fragment at the transition from rain forest to mixed deciduous forest in the municipality of Anchieta, SC, Brazil.

\section{Materials and Methods}

\section{The study area}

It is a forest fragment located in the municipality of Anchieta, Santa Catarina, Brazil (26 29' 48,14" S and 53 $20^{\circ}$ '40,37' W), altitude $627 \mathrm{~m}$ (Figure 1). The study area ( $45 \mathrm{ha}$ ) is defined by areas of agricultural production and animal husbandry. The vegetation typical of municipality is characterized by the deciduous seasonal Forest (approximately $85 \%$ of the city) and the Mixed Ombrophylous Forest (approximately $15 \%$ of the city) being considered as a transition area between the two forest types forest of the Atlantic Forest biome (Canci \& Brassiani 2004).

The Ombrophylous Forest is characterized by mixed forest of Araucaria, is one type of vegetation of the Southern Plateau (Instituto... 1992). The Araucaria Forest is a typical vegetation of the highlands and subtropical regions above $500 \mathrm{~m}$ altitude, which has suffered very serious aggression over the ages (Leivas \& Fischer 2008).

The deciduous forest or tropical deciduous forest vegetation is characterized by two well-defined seasons, a rainy period followed by long dry biologically (Instituto... 1992). Occurs in the form disjunctions presenting forest stratum and dominant macro mesofanerófito predominantly deciduous with more than $50 \%$ of individuals devoid of foliage in the unfavorable period (Instituto... 1992).

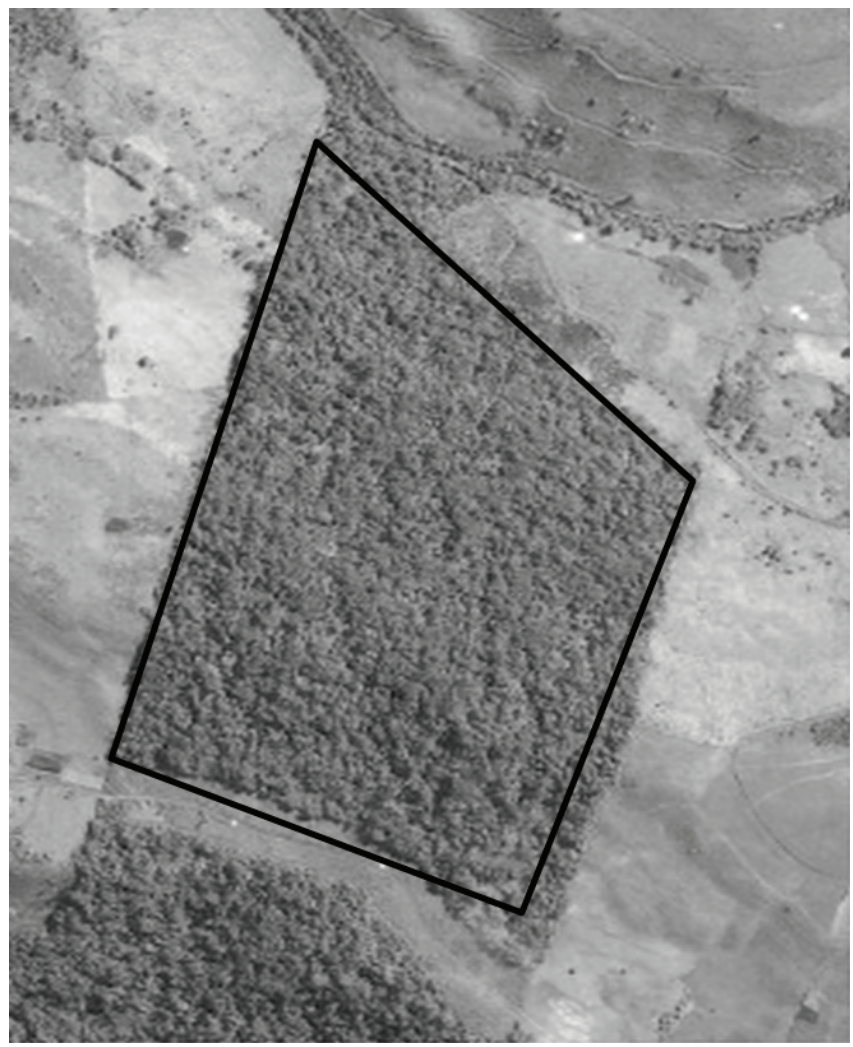

Figure 1. Area (highlighted in black) for waiver of the edaphic entomofauna (26 $29^{\circ} 48,14^{\prime \prime} \mathrm{S}$ and $53^{\circ} 20^{\prime} 40,37^{\prime} \mathrm{W}$ ), altitude $627 \mathrm{~m}$, Anchieta, SC Brazil. Source: Google Earth (2010).

Figura 1. Área (destacada em preto) de levantamento da entomofauna edáfica ( $26^{\circ} 29^{\prime} 48,14^{\prime \prime}$ S e $53^{\circ} 20^{\prime} 40,37^{\prime \prime}$ O), altitude $627 \mathrm{~m}$, Anchieta, SC Brasil. Fonte: Google Earth (2010). 
The city is inserted in the Uruguay River Basin and the climate following the classification Koeppen, is mesothermal Cfa, with defined seasons and frost in winter. The annual average temperature is $18^{\circ} \mathrm{C}$ and average annual rainfall is 1.900 to $2.000 \mathrm{~mm}$ (Instituto... 1996).

An estimated the area covered by the municipality of Anchieta, is composed of $10 \%$ of flat terrain, $15 \%$ of wavy relief and $75 \%$ mountainous, with altitudes ranging from 500 to 950 meters (Canci \& Brassiani 2004)

\subsection{Data collection}

Have been distributed 30 pitfall traps (Figure 2) arranged in three transects (A, B and C) $50 \mathrm{~m}$ the inside rim the forest and $100 \mathrm{~m}$ distant from one transect to another. Each consisting of 10 traps 10 meters distant from each other.

Traps were placed in a straight line, with the help of measuring tape and compass, and demarcated with stakes, using a wire between a pole and another to identify where the trap was set.

Samples were collected from May to August 2010, every 15 days, with two collections per month, totaling eight collections. The traps used are pitfall traps, consisting of disposable bottles of $10 \mathrm{~cm}$ in diameter and $15 \mathrm{~cm}$ high, with a capacity of $500 \mathrm{~mL}$, according to work by Aquino et al. (2006), containing 70\% alcohol, water and a few drops of detergent to break the surface tension of the same. These bottles were buried in the ground level of the litter, remaining active for 24 hours. The pitfall trap is characterized by a data collection instrument to be very simple, easily confectioned, inexpensive and easy to be transported and installed, performing efficiently and effectively. It is used to capture different groups of animals, from microinvertebrados, which make up the soil fauna, even small mammals, allowing to collect species of nocturnal and diurnal (Lopes 2007, Santos et al. 2007).

In this study, after collection, samples were stored in stoppered vials being used pet bottles of $500 \mathrm{~mL}$, containing $70 \%$ ethanol, labeled with the same number of field sample and taken to the laboratory of Zoology and Botany of University of Western Santa Catarina (UNOESC) Campus Sao Miguel do Oeste, SC, Brazil, where the collected material has undergone a process of removing of the content contained in the trap (mostly water) using a fine mesh.

Subsequently were observed using a stereoscopic microscope, quantified and identified by order level using dichotomic key (Da Costa Lima 1938). The diversity index was calculated by Simpson's Diversity Index and Shannon Index. Also, it were

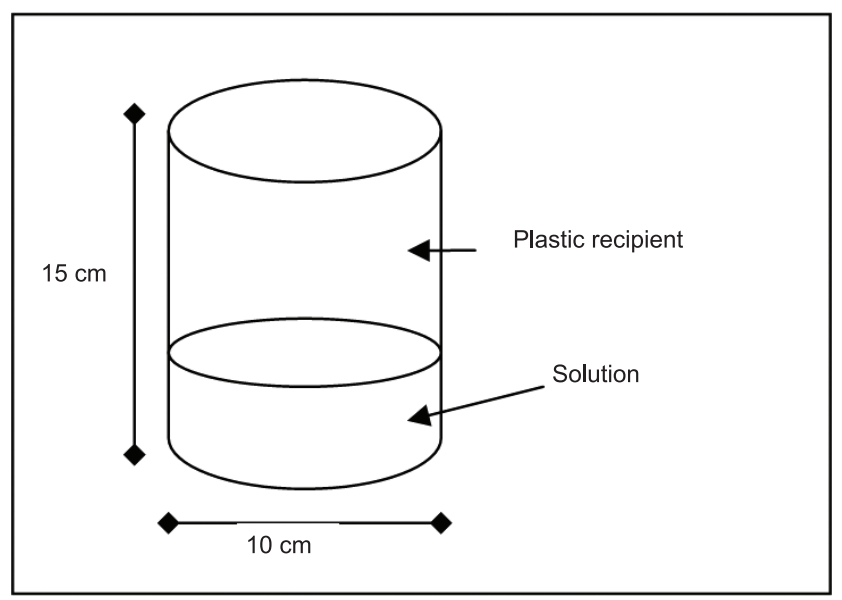

Figure 2. Schematic design of pitfall trap.

Figura 2. Desenho esquemático de armadilha tipo pitfall trap. calculated the analysis of variance (ANOVA) for the months of samples.

\section{Results and Discussion}

During the sample period, were captured 6598 individuals distributed in eight orders (Table 1). The order Hymenoptera predominated in the environment studied, with $51 \%$ of all animals captured. The Collembola are next with $21 \%$ and $14 \%$ with Order Diptera. Orthoptera and Coleoptera had the same percent (5\%). Plecoptera showed $2 \%$ and Blattaria and Hemiptera with $1 \%$ of total edaphic fauna captured.

The results of this study were similar to those of Mota et al. (2009) and Rovedder et al. (2009) in relation to the prevalence of Hymenoptera in the total number of individuals collected.

According Rovedder et al. (2009) the prevalence of Hymenoptera in the samples taken by them, indicated a tendency to low levels of diversity in the ecosystem, which may be related to low natural fertility of the soil under study.

Table 1. Total individuals captured in pitfall traps in forest fragment in the municipality of Anchieta, SC, Brazil, from May-August, 2010.

Tabela 1. Total de indivíduos capturados em armadilhas pitfall traps em fragmento florestal no município de Anchieta, SC, Brasil, no período de maio-agosto, 2010.

\begin{tabular}{lcc}
\hline \multicolumn{1}{c}{$\begin{array}{c}\text { Groups } \\
\text { collected }\end{array}$} & $\begin{array}{c}\text { Number of } \\
\text { individuals }\end{array}$ & $\begin{array}{c}\text { Percentage of } \\
\text { individuals }\end{array}$ \\
\hline Hymenoptera & 3398 & $51 \%$ \\
Collembola & 1370 & $21 \%$ \\
Diptera & 910 & $14 \%$ \\
Coleoptera & 327 & $5 \%$ \\
Orthoptera & 316 & $5 \%$ \\
Plecoptera & 166 & $2 \%$ \\
Hemiptera & 58 & $1 \%$ \\
Blattaria & 53 & $1 \%$ \\
Simpson index & 0.60 & - \\
Shannon Diversity Index & 3.00 & - \\
Total & 6598 & $100 \%$ \\
\hline
\end{tabular}

Table 2. Number of edaphic animals collected in forest fragment in the municipality of Anchieta, SC, Brazil, emphasizing the abundance of orders collection in each month.

Tabela 2. Número de animais edáficos coletados em fragmento florestal no município de Anchieta, SC, Brasil, destacando a abundância das Ordens em cada mês de coleta.

\begin{tabular}{lcccc}
\hline \multirow{2}{*}{ Order } & \multicolumn{4}{c}{ Number of individuals } \\
\cline { 2 - 5 } & May & June & July & August \\
\hline Hymenoptera & 132 & 2333 & 699 & 234 \\
Collembola & 283 & 386 & 254 & 447 \\
Diptera & 296 & 237 & 172 & 205 \\
Coleoptera & 35 & 127 & 95 & 70 \\
Orthoptera & 99 & 81 & 87 & 51 \\
Plecoptera & 31 & 39 & 45 & 49 \\
Hemiptera & 15 & 10 & 15 & 18 \\
Blattaria & 20 & 16 & 11 & 6 \\
Mean & 113,88 ns & 403,63 ns & $172,25 \mathrm{~ns}$ & 135,00 ns \\
TOTAL & 911 & 3229 & 1378 & 1080 \\
\hline ns no significant difference & \multicolumn{3}{c}{}
\end{tabular}


For this study, the Hymenoptera were not predominant on all collections. That is, were the most abundant only in June and July (two samples), as can be seen in Table 2.

The results obtained by Cunha (2004) suggest occurrence of an great accumulation the leaflitter which allows the coexistence of many species of macroinvertebrates, and after that accumulation, the ants (Hymenoptera) dominate the leaflitter, predating or expelling the others arthropods.

According Pereira \& Silva (2009) the ants indicate the biodiversity from areas with environmental disturbance. Complementing, Lopes (2008) argues that the presence of the order Hymenoptera, indicated environment degradation. However, to use the ants as bioindicators is required a detailed analysis, not being possible to examine the environmental impacts or a regeneration effect on a simple count of their number (Neves et al. 2008).

According Santos et al. (2007), alcohol can be an attractive for the orders Coleoptera and Hymenoptera. This can also explain the appearance of large number of ants in this study because been used alcohol in the interior of pitfall traps.

The Order Collembola, which was the second most abundant in number of individuals and remained practically stable in all collections of the study, the functional role in processes involving the dynamic of the organic matter and the sensitivity to disturbances can be considered effective for a good indicator of soil quality (Assad 1997).

Thus, the number of Collembola collected in the study area, although for a short period of time, can say that the forest fragment provides conditions for survival for these individuals and, consequently, it is a place with good soil.

The Diptera represented the third order most commonly found (Table 1), confirming that the study site gives conditions for the development of these insects, indicating low or absence of of contamination in the soil.

According to Correia (2002) and Leivas \& Fischer (2008), the Diptera show great importance on the restoration of areas, playing a major role in the colonization of environments and in nutrient cycling across its larvae phytophagous, saprophagous, microphagous and micetophagous just colonized environments which support the development of their larvae.

In terms the Order Coleoptera, was the most abundant just in June (Table 2). Zardo et al. (2009) in his study on Arthropods communities associated with leaflitter forest stands that the abundance of order Coleoptera is positively related to the depth of the litter. As the collections of the present study were carried out with pitfall traps, it is possible the number of individuals captured of the Order Coleoptera, is not effectively expressed, future studies being needed to other methods of collection for more accurate results. The presence of the Coleoptera could be related to his ownership of animal breeding (cattle raising) next to the fragment, which may be in the Coleoptera that feed on the feces of vertebrates.

The presence of the Order Blattaria, although with small representativeness in the fragment studied, complements the fact that it is an area with good levels of organic matter, because, according to Lopes (2008) the order Blattaria require high organic matter content, in other words, only in places and more balanced variety of foods these animals could be encountered.

Some families of Orthoptera are greatly influenced for the availability of moist environment (Mól et al. 2007). In this forest fragment was verified that the soil is moist enough to allow good state to develop the Orthoptera.

Lopes (2008) argues that the orders Blattaria, Diptera and Coleoptera can be found in preserved environments.
The orders Plecoptera and Hemiptera did not have very significant results. However is believed that the presence of order Plecoptera is related to the small stream running passing through the fragment, because their larvae develop in water (Callisto et al. 2004).

Already members of order Hemiptera, which may be considered agricultural pests and also natural enemies (Brusca \& Brusca 2007). Possibly, in this study were present because there agricultural production areas near the study area or because they are of this specific habitat.

The value of Simpson index was found to be 0.60 . The Shannon Diversity Index was 3.00

The Simpson and Shannon index indicate that there is encountered a good diversity in the forest fragment studied. This is justified because the Simpson index is a dominance index and reflects the probability that two randomly chosen individuals in the community belong to the same species. Ranges from 0 to 1 and the higher, the more likely individuals are the same species, ie higher dominance and lower diversity (Uramoto et al. 2005). Already the Shannon index measures the level of uncertainty to predict to what species belong to one individual chosen at random from a sample of $\mathrm{S}$ species and $\mathrm{N}$ individuals. The lower the value of the Shannon index, the lower the degree of uncertainty and therefore the diversity of the sample is low. The diversity tends to be higher the higher the index value (Uramoto et al. 2005).

By analysis of variance was not significant difference among month of observation. However, compared to the months of collection, the month of May had the lowest number of individuals and in June was what had the highest number of samples (Table 2).

The pluviometric precipitation between the months May to August varied greatly, with the month of greater precipitation in May it was the $231.3 \mathrm{~mm}$. And the month of less precipitation in June was $30.2 \mathrm{~mm}$ (Empresa... 2010). Whereas the temperatures have already had between $14.9{ }^{\circ} \mathrm{C}$ to $16.3{ }^{\circ} \mathrm{C}$ (Empresa... 2010). That indicates that the animals were more abundant in the driest months.

Faced with the results obtained, it were observed that the forest fragment studied provide favorable conditions to insects and consequently presented good quality of soil. However there is need of greater surveying related to fauna as bioindicators of soil because this survey was conducted only in autumn and winter season and is known to that the class Insecta is more abundant in the warm season.

\section{Acknowledgements}

To God, the great force that drives us. The Program University for All (PROUNI) for granting the scholarship integral study to the first author. To all who in one way or another have contributed to this study.

\section{References}

ALMEIDA, L.M. 1998. Manual de coleta, conservação, montagem e identificação de insetos. Ed. Holos, 71p.

AQUINO,A.M., MENEZES, E.L.A. \& QUEIROZ, J.M. 2006. Recomendações para coleta de artrópodes terrestres por armadilhas de queda ("Pitfall Traps"). Embrapa, Seropédica. Circular técnica.

ASSAD, M.L.L. 1997. Fauna do solo. Biologia dos solos dos Cerrados. Embrapa, Planaltina, p.363-443.

BARBOSA, J.H.C. \& FARIA S.M. 2006. Aporte de serrapilheira ao solo em estágios sucessionais florestais na reserva biológica de poço das Antas, Rio de Janeiro, Brasil. Rodriguésia 57(3):461-476.

BRUSCA, R.C. \& BRUSCA, G.J. 2002. Invertebrates. 2. ed. Sinauer Associates, Massachusetts, 936p.

BRUSCA, R.C. \& BRUSCA, G.J. 2007. Invertebrados. 2. ed. Rio de Janeiro, Guanabara Koogan, 968p. 
CALLISTO, M., GONÇALVES JUNIOR, J.F. \& MORENO, P. 2004. Invertebrados aquáticos como bioindicadores. In Navegando o Rio das velhas das Minas aos Gerais (E.M.A. Goulart). UFMG, Belo Horizonte, v.1, p.1-12.

CANCI, I. \& BRASSIANI, I.A. 2004. Anchieta História, memória e experiência: uma caminhada construída pelo povo. McLee, São Miguel do Oeste, 418p.

CORREIA, M.E.F. 2002. Potencial de utilização dos atributos das comunidades de fauna de solo e de grupos chave de invertebrados como bioindicadores do manejo de ecossistemas. Embrapa, Seropédica. Embrapa Documentos, n.157.

COSTA-RIBEIRO, C.S. \& ROCHA, R.M. 2002. Invertebrados: manual de aulas práticas. Holos, Ribeirão Preto, 226p.

CULLEN JUNIOR, L., RUDRAN, R. \& PADUA, C.V. 2006. Métodos de estudo em Biologia da Conservação \& Manejo da Vida Silvestre. 2. ed. UFPR, Curitiba, 651p.

CUNHA, N.L. 2004. Artropodos associados a serrapilheira suspensa acumulada em folhas de duas palmeiras, Amazônia Central. INPA. Curso de campo: Ecologia da Floresta Amazônica.

DA COSTA LIMA, A.M. 1938. Insetos do Brasil. Escola Nacional de Agronomia. Série didática, n.2.

DAMBROZ, J., MEDEIROS, E.P., COELHO R.T. \& IOCCA F.A.S. 2007. Entomofauna da Fazenda Iracema na estação seca, município de ClaudiaMT. In VIII Congresso de Ecologia do Brasil. Caxambu.

DINDAL, D.L. 1990. Soil Biology Guide. John Wiley, New York, 1349p.

EMPRESA DE PESQUISA AGROPECUÁRIA E EXTENSÃO RURAL DE SANTA CATARINA - EPAGRI. 2010.

FERREIRA, R.L. \& MARQUES, M.M.G.S.M. 1998. A fauna de artrópodes de serrapilheira de áreas de monocultura com Eucalyptus sp. e mata secundária heterogênea. An. Soc. Entomol. Bras. 27(3):395-403. http:// dx.doi.org/10.1590/S0301-80591998000300007

INSTITUTO BRASILEIRO DE GEOBRAFIAE ESTATÍSTICA-IBGE. 1992. Manual técnico da vegetação brasileira. Rio de Janeiro, 91p. Série: manuais técnicos em geociências.

INSTITUTO BRASILEIRO DE GEOBRAFIAE ESTATÍSTICA-IBGE. 2006. Censo Agropecuário. IBGE.

LEIVAS, F.W.T. \& FISCHER, M.L. 2008. Avaliação da composição de invertebrados terrestres em uma área rural localizada no município de Campina Grande do Sul, Paraná, Brasil. Biotemas 21(1):65-73.

LOPES, B.G.C. 2008. Levantamento da entomofauna bioindicadora da qualidade ambiental em diferentes áreas do alto jequitinhonha - Minas Gerais. Monografia de graduação, Escola Agrotécnica Federal de Inconfidentes, Inconfidentes.

LOPES, J. 2007. Evolução metodológica no uso de armadilhas tipo pitfall para coleta da entomofauna de solo. In VIII Congresso de Ecologia do Brasil. Caxambu.
MÓL, A.P., NAGAI, M.E., PEREIRA, M.R., ALMEIDA, S.S.P., SPERBER, C.F. \& RIBEIRO S.P. 2007. Interação entre processos ecológicos e geomorfológicos na diversidade e abundância de grilos (Orthoptera:Grylloidea) de serrapilheira florestal. In VIII Congresso de Ecologia do Brasil. Caxambu.

MOTA, B.C.F., RODRIGUES, L.A., SOUZA, L.M., FERNANDES, M.F.G., OLIVEIRA, T.T. \& VELOSO, M.D.M. 2009. Diversidade de artrópodes terrestres capturados em pitfall traps em área de Cerrado strictu sensu e Mata Ciliar. In Fórum de Ensino, Seminário de Pesquisa e pós-graduação, Seminário de Iniciação Científica, Mostra Científica do Ensino Médio, Semana da Extensão. Universidade Estadual de Montes Claros.

NEVES, F.S., MADEIRA, B.G., OLIVEIRA, V.H.F. \& FAGUNDES, M. 2008. Insetos como bioindicadores dos processos de regeneração em matas secas, MG. Biota 1(1):46-53.

NUNES, L.A.P.L., ARAÚJO FILHO, J.A. \& MENEZES, R.Í.Q. 2009. Diversidade da fauna edáfica em solos submetidos a diferentes sistemas de manejo no semi-árido nordestino. Sci. Agrar. 10(1):043-049.

PEREIRA, A.C.F. \& SILVA, H.S. 2009. Levantamento da entomofauna noturna de uma região antropizada no norte de minas gerais. Anais... São Lourenço, MG.

ROVEDDER, A.P.M., ELTZ, F.L.F., DRESCHER, M.S., SCHENATO, R.B. \& ANTONIOLLI, Z.I. 2009. Organismos edáficos como bioindicadores da recuperação de solos degradados por arenização no Bioma Pampa. Cienc. Rural 39(4):1061-1068. http://dx.doi.org/10.1590/S010384782009005000023

SANCHES, L., VALENTINI, C.M.A., BIUDES, M.S. \& NOGUEIRA, J.S. 2009. Dinâmica sazonal da produção e decomposição de serrapilheira em floresta tropical de transição. Rev. Bras. Eng. Agric. Ambient. 13(2):183-189. http://dx.doi.org/10.1590/S141543662009000200012

SANTOS, S.A.P., CABANAS, J.E. \& PEREIRA, J.A. 2007. Abundance and diversity of soil arthropods in olive grove ecosystem (Portugal): Effect of pitfall trap type. Eur. J. Soil Biology. 2007(43):77-83.

STORER, T.I. 2003. Zoologia Geral. Editora nacional, São Paulo, 816p.

THOMAZINI, M.J. \& THOMAZINI, A.P.B.W. 2000. A fragmentação florestal e diversidade de insetos nas florestas tropicais úmidas. Embrapa Acre, Rio Branco. Documentos Embrapa, n.57.

URAMOTO, K., WALDER, J.M.M. \& ZUCCHI, R.A. 2005. Análise Quantitativa e Distribuição de Populações de Espécies de Anastrepha (Diptera: Tephritidae) no Campus Luiz de Queiroz. Neotrop. Entomol. 34(1):33-39. http://dx.doi.org/10.1590/S1519566X2005000100005

ZARDO, D.C., CARNEIRO, A.P., LIMA, L.G., MUNIZ, C. \& SANTOS FILHO, M. 2009. Comunidade de artrópodes associada a serapilheira de serrado e mata de galeria,na estação ecológica Serra das Araras, Mato Grosso, Brasil. In IX Congresso de Ecologia do Brasil. SEB, São Lourenço. 